\title{
Investigasi Difusi pada Sistem Urinari untuk Gangguan Fungsi Ginjal Model Empat Kompartemen menggunakan Metode Monte Carlo
}

\author{
Jovi Yuzzer Budiman, Jodelin Muninggar, dan Adita Sutresno* \\ Fisika, Fakultas Sains Dan Matematika, Universitas Kristen Satya Wacana \\ Jl. Diponegoro 52-60 Salatiga 50711
}

\begin{abstract}
Intisari
Ginjal merupakan sepasang organ pada sistem urinari yang berfungsi untuk menyaring darah dan pembentukan urin. Pembentukan urin yang dilakukan melalui salah satu proses yaitu reabsorpsi tubulus. Proses ini merupakan proses difusi baik secara pasif maupun terfasilitasi. Proses terjadi di tubulus pada ginjal dapat disimulasikan dengan menggunakan simulasi permodelan Monte Carlo Cell. Pembuatan model 4 kompartemen yang terdiri dari pembuluh darah, 2 ginjal dengan salah satu ginjal mengalami penurunan fungsi ginjal dan kandung kemih. Dua kompartemen ginjal dengan salah satu ginjal yang mengalami penurunan fungsi berpengaruh pada proses difusi yang terjadi saat proses reabsorpsi zat pada ginjal.Tujuan penelitian ini adalah untuk mempelajari proses difusi yang terjadi pada ginjal dengan penentuan beberapa variabel tetap dan indikator yang akan diamati menggunakan simulasi Monte Carlo Cell. Penggunaan simulasi Monte Carlo Cell memungkinkan untuk mencoba segala probabilitas yang terjadi pada dalam proses difusi pada filtrasi, reabsorpsi dan sekresi dalam ginjal.Hasil dari penelitian menunjukan bahwa semakin sedikit jumlah lubang maka perpindahan molekul semakin lambat dan juga semakin sedikit jumlah molekul permukaan maka perpindahan molekul semakin lambat.
\end{abstract}

\begin{abstract}
The kidney is a pair of an organ in our urinary system that function to filter blood and urine establishment through filtration, reabsorption and secretion process. Formation of urine is done through one of processes, named tubular reabsorption. This process is a process of diffusion, passively and facilitated. The process that happens in tubular reabsorption in the kidney can be simulated by using the Monte Carlo Cell simulation. Making a model of 4 compartments consists of blood vessels, 2 kidneys with one kidney experiencing the decreased function of the kidney and bladder. Two kidney compartments with one of it experiencing decreased function affect the diffusion process that happens in the substance reabsorption process in the kidney. The purpose of this research is to study the diffusion process which happens in the kidney by selecting several fixed variable and indicators which will be inspected by using the Monte Carlo Cell simulation. The use of Monte Carlo Cell simulation enables to try any probabilities that occur in the diffusion process of filtration, reabsorption, and secretion processing kidney. The result of this research shows that the fewer the number of molecules, the slower the molecular displacement and also the fewer number of surface molecules, the slower the molecular displacements.
\end{abstract}

Keywords: diffusion; Kidney; Monte Carlo Cell.

*Corresponding author: adita@staff.uksw.edu

http://dx.doi.org/10.12962/j24604682.v16i1.5063

2460-4682 (CDepartemen Fisika, FSAD-ITS

\section{PENDAHULUAN}

Ginjal merupakan sepasang organ pada sistem urinari dan terletak di rongga retroperitoneal bagian atas [1] yang berfungsi untuk filtrasi darah, reabsorpsi dan sekresi dengan proses difusi pada sistem penyaringan darah dan pembentukan urin [2]. Pembentukan urin yang mengandung zat sisa oleh ginjal melalui tiga proses utama yakni filtrasi glomerulus, reabsorpsi tubulus dan sekresi tubular. Filtrasi glomerulus merupakan perpindahan cairan dan zat terlarut dari kapiler glomerula menuju dalam kapsula bowman dengan perbedaan tekanan dan membran sebagai faktor yang mempengaruhi proses filtrasi. Reabsorpsi tubulus merupakan proses menyerap kembali sebagian besar zat yang masih berguna untuk tubuh melalui proses difusi pasif dan difusi terfasilitasi dengan sekitar $85 \%$ zat pada filtrat glomerulus diabsorpsi pada tubulus kontortus proksimal dan secara keseluruhan terjadi dalam nefron. Sekresi tubular merupakan perpindahan selektif zatzat kapiler darah ke dalam lumen tubulus [3].

Proses reabsorpsi pada ginjal yang melibatkan proses di- 
fusi terfasilitasi dapat disimulasikan menggunakan simulasi Monte Carlo Cell dengan pembuatan 4 kompartemen yaitu kompartemen pembuluh darah, 2 kompartemen ginjal dengan salah satu ginjal mengalami penurunan fungsi ginjal dan kompartemen kandung kemih. Simulasi dilakukan dengan mengubah beberapa indikator. Simulasi yang pertama dilakukan adalah mengubah jumlah lubang pada salah satu ginjal yang mengalami penurunan fungsi ginjal yang berpengaruh pada nilai luas saluran pada permukaan dan simulasi yang kedua adalah mengubah jumlah molekul permukaan yang berpengaruh pada kerapatan permukaan. Mengurangi jumlah lubang dan molekul permukaan pada salah satu kompartemen ginjal dapat merepresentasikan penurunan fungsi ginjal pada proses reabsorpsi yang dilakukan sebagian oleh nefron [3]. Nefron yang mengalami proses maladaptasi berupa sklerosis nefron menyebabkan terganggunya proses reabsorpsi pada ginjal yang menjadi penyebab utama penyakit gagal ginjal kronis [4].

Penelitian ini bertujuan untuk mempelajari proses difusi yang terjadi pada reabsorpsi ginjal dengan penentuan beberapa variable tetapdan indikator yang akan diamati. Dari penelitian yang telah dilakukan, penggunaan metode modeling 3-D Monte Carlo Cell dapat digunakan dalam penelitian ini dikarenakan Monte Carlo Cell dapat menggunakan atau mengandalkan bilangan acak, geometri objek dan adanya pergerakan partikel yang dapat teramati [5].

Difusi adalah proses penyebaran molekul-molekul suatu zat yang ditimbulkan oleh gaya yang identik dengan energi kinetik dan menyebar ke segala arah hingga terdapat suatu konsentrasi yang sama. Difusi zat terjadi dari suatu tempat yang banyak mengandung molekul-molekul atau tempat yang konsentrasinya tinggi menuju tempat yang sedikit mengandung molekul atau konsentrasi rendah [6]. Secara matematis, persamaan difusi ditentukan dalam hukum Fick I dan II [7]:

$$
\begin{aligned}
& \text { Hukum Fick I }: \Theta=D \frac{\partial C}{\partial y} \\
& \text { Hukum Fick II }: \frac{\partial[C]}{\partial t}=D \frac{\partial^{2}[C]}{\partial y^{2}}
\end{aligned}
$$

Serta persamaan arus difusi secara matematis, [5]

$$
I=4 N D s C
$$

Persamaan hukum Fick I dapat digunakan untuk mengamati perubahan jumlah molekul permukaan pada ginjal yang mengalami penurunan fungsi ginjal. Hukum Fick I yaitu $\Theta$ adalah jumlah zat (mol) per luas permukaan yang dilalui zat untuk setiap detiknya $\left(\Theta=\mathrm{mol} / \mathrm{m}^{2} \mathrm{~s}\right)$. Hukum Fick II serta arus difusi dapat digunakan untuk mengamati perubahan jumlah lubang yang berpengaruh pada luas saluran difusi dimana hal tersebut mempengaruhi arus difusi yang berbanding lurus dengan luas saluran difusi.

\section{METODOLOGI}

Simulasi pada penelitian ini dilakukan menggunakan Aplikasi Blender $2.76 \mathrm{~b}$ dengan add-on CellBlender for MCell

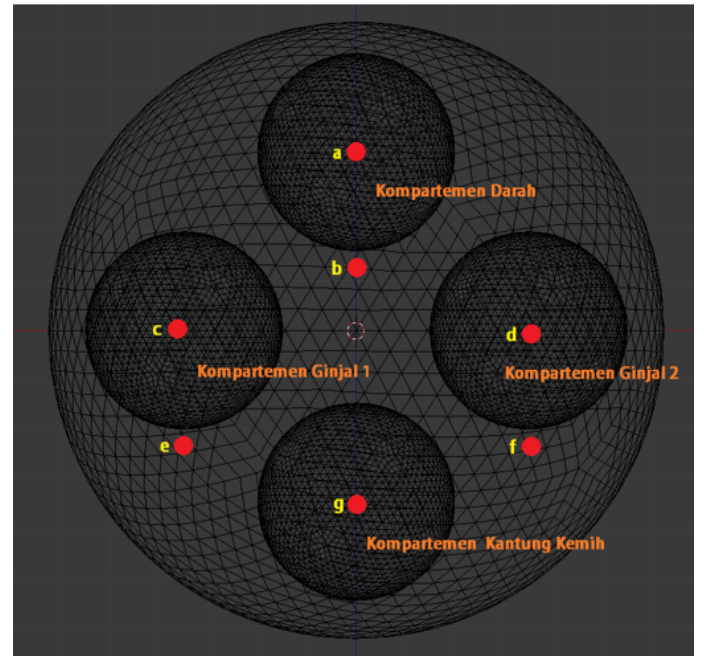

Gambar 1: Model kompartemen sistem urinari.

dan dijalankan dengan PC (Personal Computer) Windows 7 Intel Core i7-6700 CPU @ 3,40 GHz GPU NVIDIA GeForce GTX 960.

Sistem urinari dimodelkan dengan 4 (empat) kompartemen: pembuluh darah, 2 ginjal dengan salah satu ginjal mengalami penurunan fungsi ginjal dan kandung kemih. Model kompartemen digambarkan seperti pada Gambar 1 .

Simulasi dilakukan dengan proses reversibel dengan molekul yang dari kompartemen ginjal masuk ke dalam kompartemen kandung kemih akan memungkinkan molekul tersebut kembali ke kompartemen ginjal.

Konstanta difusi di kompartemen terdiri dari 2 konstanta difusi yakni konstanta difusi didalam kompartemen (VolM) dan konstanta difusi dipermukaan kompartemen (SurfM). Simulasi ini terdiri dari beberapa tahap. Pertama, molekul di dalam kompartemen darah (VolMa) berinteraksi dengan molekul permukaan kompartemen darah (SurfMa) dengan proses reversibel dan menghasilkan molekul di kompartemen Cell (VolMb). Kedua, molekul yang berada di kompartemen Cell yang ada di antara kompartemen ginjal dan darah (VolMb) akan masuk ke dalam kedua ginjal yang dimana ginjal 1 adalah keadaan ginjal normal dan ginjal 2 merupakan ginjal yang mengalami penurunan fungsi ginjal. Molekul kompartemen Cell (VolMb) berinteraksi dengan molekul permukaan ginjal 1 yang berada di bagian atas kompartemen (SurfMc1) menghasilkan molekul di kompartemen ginjal 1 (VolMc) yang juga terjadi di ginjal 2 yakni molekul kompartemen Cell (VolMb) berinteraksi dengan molekul permukaan ginjal 2 yang berada di bagian atas kompartemen (SurfMd1) menghasilkan molekul di kompartemen ginjal 2 (VolMd). Ketiga, molekul ginjal 1 (VolMc) berinteraksi dengan molekul permukaan ginjal 1 yang berada di bagian bawah kompartemen (SurfMc2) menghasilkan molekul pada kompartemen Cell yang berada diantara kompartemen ginjal 1 dan kandung kemih bagian bawah (VolMe) dan juga terjadi di ginjal 2 yakni molekul ginjal 2 (VolMd) berinteraksi dengan molekul permukaan ginjal 2 yang berada di bagian bawah kompartemen (SurfMd2) menghasilkan molekul pada 


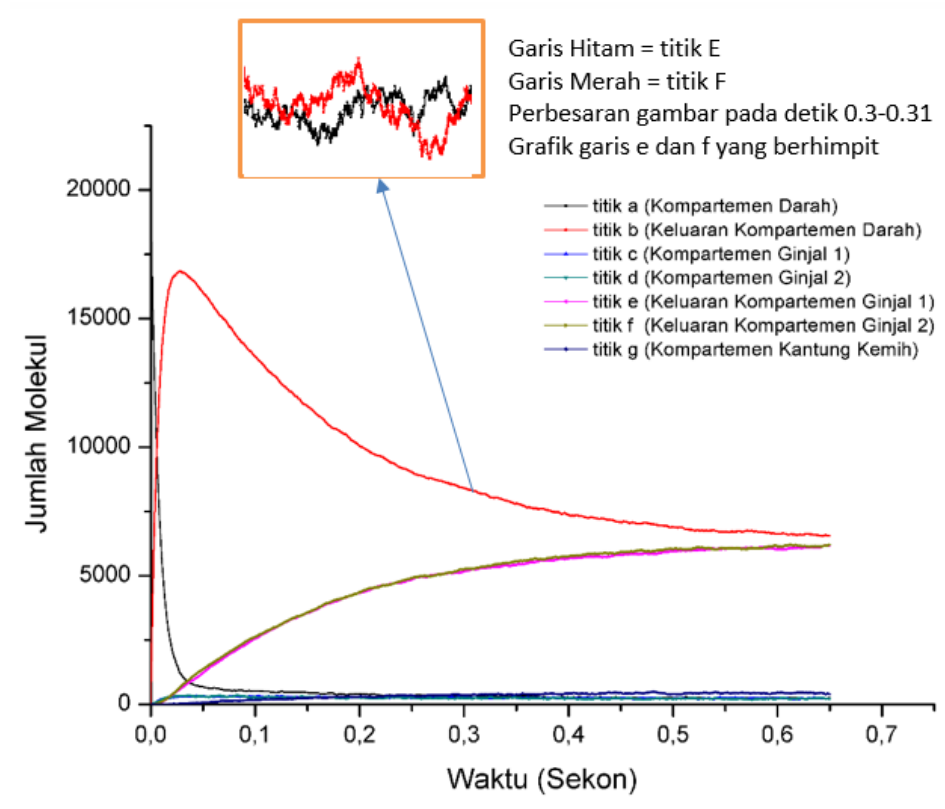

Gambar 2: Hasil pengambilan data dari ginjal normal (36 lubang).

kompartemen Cell yang berada diantara kompartemen ginjal 2 dan kandung kemih bagian bawah (VolMf). Keempat, molekul kompartemen Cell yang letaknya di bagian bawah ginjal 1 (VolMe) akan berinteraksi dengan molekul permukaan kandung kemih (SurfMg) menghasilkan molekul kompartemen kandung kemih (VolMolg) dan juga terjadi pada molekul kompartemen Cell yang letaknya di bagian bawah ginjal 2 (VolMolf) menghasilkan molekul kompartemen kantung kemih (VolMolg).Gambaran lebih detail interaksi antar molekul dari masing-masing kompartemen dapat dilihat sebagai berikut

$$
\begin{aligned}
& \text { VolMa+SurfMa } \Longleftrightarrow \operatorname{SurfMa+VolMb} \\
& \text { VolMb+SurfMc1 } \Longleftrightarrow \operatorname{SurfMc1}+\text { VolMc } \\
& \text { VolMb }+ \text { SurfMd1 } \Longleftrightarrow \operatorname{SurfMd1+VolMd} \\
& \text { VolMc+SurfMc2 } \Longleftrightarrow \operatorname{SurfMc2}+\text { VolMe } \\
& \text { VolMd }+ \text { SurfMd2 } \Longleftrightarrow \operatorname{SurfMd} 2+\text { VolMf } \\
& \text { VolMe }+ \text { Surf } M g \Longleftrightarrow \operatorname{SurfMg}+\operatorname{Vol} M g \\
& \text { VolMf }+ \text { SurfMg } \Longleftrightarrow \text { SurfMg }+ \text { VolMg }
\end{aligned}
$$

Indikator yang digunakan dalam proses simulasi ini meliputi 2 (dua) indikator, pertama menurunkan banyaknya jumlah lubang pada ginjal 2 berturut-turut dari 36, 30, 24, 18, 12 dan kedua mengganti besar jumlah molekul untuk mempengaruhi pengaruh kerapatan terhadap laju difusi yang terjadi. Pengaruh indikator pertama dan kedua akan direpresentasikan dengan grafik $t_{0,5}$ terhadap kedua indikator tersebut. Grafik $\mathrm{t}_{0,5}$ diperoleh dengan cara mengurangi jumlah molekul di puncak grafik dengan molekul akhir dan kemudian hasilnya dibagi 2 yang setelah itu hasil yang didapatkan kemudian dikurangi dengan jumlah molekul pada puncak grafiknya tersebut. Pada proses simulasi yang kedua, jumlah lubang pada ginjal 1 sebesar 36 lubang dan ginjal 2 sebesar 30 lubang untuk membedakan ginjal normal dengan yang mengalami penurunan fungsi ginjal serta membedakan jumlah molekul pada ginjal 2 sebesar 30, 25, 20, 15 dan 10 molekul.

\section{HASIL DAN DISKUSI}

Pada simulasi yang pertama, pengamatan difokuskan pada perbedaan jumlah lubang antara kedua ginjal dengan ginjal pertama sebanyak 36 lubang dan ginjal kedua mengalami penurunan sebanyak 6 lubang hingga mencapai 12 lubang saja yang dimana berarti hal ini merupakan sebuah penurunan fungsi ginjal secara terus menerus sehingga fungsi ginjal menjadi minim. Molekul pada permukaan dibuat tetap sebesar 2000 molekul karena pada saat molekul sudah sebesar 2000, kerapatan tiap penurunan lubang sudah diatas $10^{4}$ yang berarti kerapatan dianggap bernilai sama dengan $10^{4}$ [8]. Perpindahan molekul terjadi dari kompartemen darah melewati kedua ginjal hingga sampai di kandung kemih.

Pada Gambar 2 merupakan data yang didapatkan pada sistem urinari yang memiliki 2 ginjal normal. Dapat dilihat bahwa hampir tidak adanya perbedaan perpindahan molekul pada keluaran ginjal 1 dan 2 yang ditunjukan dengan grafik garis pada titik e dan $\mathrm{f}$ yang berhimpit. Titik e dan $\mathrm{f}$ merupakan representasi dari jumlah keluaran molekul kompartemen ginjal 1 dan 2 . Titik e dan $\mathrm{f}$ yang berhimpit menandakan bahwa tidak adanya perbedaan keluaran antara kedua ginjal yang normal.

Pada Gambar 3, merupakan data perpindahan molekul dari titik e ke titik $\mathrm{f}$ dengan grafik $\mathrm{t}_{0,5}$ terhadap jumlah lubang. Dapat dilihat bahwa waktu yang diperlukan dalam perpindahan molekul antar kompartemen menjadi lebih lambat pada saat kondisi lubang pada permukaan lebih sedikit. Perpindahan molekul mengalami penurunan seiring dengan penurunan jumlah lubang yang menginterpretasikan fungsi gin- 
TABEL I: Parameter yang digunakan untuk simulasi 1 dan 2.

\begin{tabular}{lll}
\hline Parameter & \multicolumn{1}{c}{$\mathrm{N}$ i 1 a i } \\
& Simulasi 1 & Simulasi 2 \\
\hline Konstanta Difusi Volume (VolM) & $1 \times 10^{-6} \mathrm{~cm}^{2} \mathrm{~s}^{-1}$ & $1 \times 10^{-6} \mathrm{~cm}^{2} \mathrm{~s}^{-1}$ \\
Konstanta Difusi Permukaan (SurfM) & $0 \mathrm{~cm}^{2} \mathrm{~s}^{-1}$ & $0 \mathrm{~cm}^{2} \mathrm{~s}^{-1}$ \\
Forward Rate (Fr) & $1 \times 10^{8} \mathrm{M}^{-1} \mathrm{~s}^{-1}$ & $1 \times 10^{8} \mathrm{M}^{-1} \mathrm{~s}^{-1}$ \\
Backward Rate (Br) & $1 \times 10^{8} \mathrm{M}^{-1} \mathrm{~s}^{-1}$ & $1 \times 10^{8} \mathrm{M}^{-1} \mathrm{~s}^{-1}$ \\
Lubang pada Ginjal 1 & 36 Lubang & $36 \mathrm{Lubang}$ \\
Lubang pada Ginjal 2 & $12-36$ Lubang & 30 Lubang \\
\multicolumn{3}{c}{ *Jarak antar objek sebenarnya pada phantom } \\
Jumlah Molekul (Ginjal 2) & (Naik sebanyak 6 lubang \\
\hline \hline
\end{tabular}

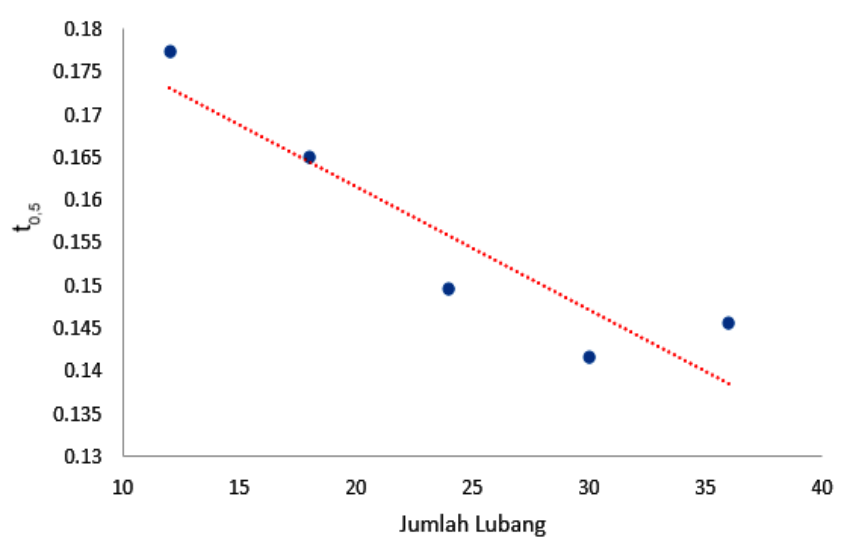

Gambar 3: Grafik $\mathrm{t}_{0,5}$ terhadap perbedaan jumlah lubang.

jal yang semakin menurun. Penurunan jumlah lubang yang berpengaruh pada arus perpindahan molekul dinyatakan pada Pers.(3). Pada penelitian ini, semakin sedikit lubang maka akan semakin kecil luas saluran difusi. Arus difusi berbanding lurus dengan luas saluran difusi. Oleh karena itu, semakin kecil luas saluran difusi, semakin besar arus difusi dan semakin cepat perpindahan molekul antar kompartemen. Nilai koefisien determinasi $\left(\mathrm{R}^{2}\right)$ pada Gambar 3 sebesar 0,842 setara dengan $84,2 \%$ yang mempunyai arti bahwa perbedaan jumlah lubang berpengaruh pada waktu yang diperlukan untuk perpindahan molekul sebesar $84,2 \%$ sedangkan sisanya (100\% $84,2 \%=15,8 \%$ ) merupakan pengaruh variabel lain diluar dari variabel yang diamati.

Pada simulasi yang kedua, perubahan jumlah molekul dilakukan pada ginjal 2 yang mengalami penurunan fungsi ginjal. Pada Gambar 4 merupakan data perpindahan molekul dari titik e ke titik $\mathrm{f}$ dengan grafik $\mathrm{t}_{0,5}$ terhadap perbedaan kerapatan yang diperoleh dari hasil perhitungan jumlah molekul per luasan permukaan. Dapat dilihat bahwa perpindahan molekul mengalami penurunan seiring dengan penurunan jumlah molekul permukaan tersebut. Semakin sedikit jumlah molekul pada permukaan yang berarti juga menjadi penyebab semakin kecilnya fluks (kerapatan), maka perpindahan molekul dari kompartemen ginjal 2 menuju keluaran di titik

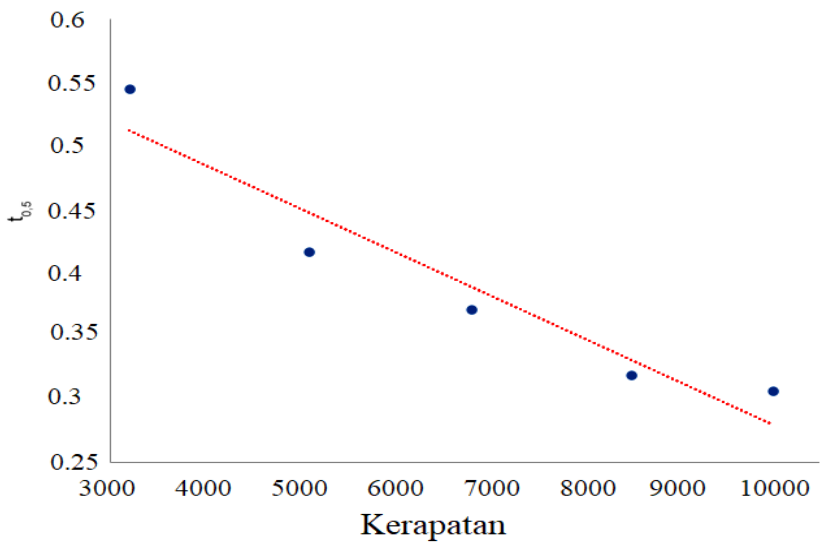

Gambar 4: Grafik t $\mathrm{t}_{0,5}$ terhadap perbedaan kerapatan.

f menjadi lebih lambat. Nilai koefisien determinasi $\left(\mathrm{R}^{2}\right)$ pada gambar 4 sebesar 0,9143 setara dengan $91,43 \%$ yang mempunyai arti bahwa perbedaan kerapatan berpengaruh pada waktu yang diperlukan untuk perpindahan molekul sebesar $91,43 \%$ sedangkan sisanya $(100 \%-91,43 \%=8.57 \%)$ merupakan pengaruh variabel lain diluar dari variabel yang diamati.

\section{SIMPULAN}

Perbedaan jumlah lubang pada simulasi pertama berpengaruh terhadap perpindahan molekul dari kompartemen satu ke kompartemen lainnya. Kompartemen ginjal yang mengalami penurunan fungsi ginjal dengan lubang yang paling sedikit mengalami perpindahan molekul yang paling lambat dibandingkan dengan ginjal normal dikarenakan adanya pengaruh dari luas saluran difusi terhadap perpindahan molekul antar kompartemen. Koefisien determinasi pada simulasi yang pertama menunjukkan angka 0,842 besarnya sama dengan $84,2 \%$ yang berarti bahwa pengaruh dari penurunan jumlah lubang sangat berdampak pada perpindahan molekul antar kompartemen yang diamati dan hanya kurang dari $20 \%$ yaitu sebesar 15,8\% dipengaruhi oleh variabel lain diluar variabel yang diamati. Perbedaan jumlah molekul permukaan 
pada simulasi kedua berpengaruh juga terhadap perpindahan molekul dari kompartemen ginjal yang mengalami penurunan fungsi ginjal ke titik $\mathrm{f}$ yang merupakan keluaran ginjal tersebut dikarenakan jumlah molekul berpengaruh terhadap kerapatan/densitas yang dimana hal tersebut berdampak pada perpindahan molekulnya. Semakin kecil kerapatan yang dimiliki, semakin lambat perpindahan molekul yang terjadi. Koefisien determinasi pada simulasi yang kedua menunjukkan angka 0,9143 besarnya sama dengan $91,43 \%$ yang berarti bahwa pengaruh dari kerapatan sangat berdampak pada perpindahan molekul antar kompartemen yang diamati dan hanya kurang dari $10 \%$ yaitu sebesar $8,57 \%$ dipengaruhi oleh variabel lain diluar variabel yang diamati.
[1] B.B. Purnomo, "Dasar-dasar Urologi", CV. Infomedika, Jakarta, 2007.

[2] W.M. Saltzman, "Biomedical Engineering”, Cambridge University Press, New York, 2009.

[3] R. Chalik, "Anatomi Fisiologi Manusia", Kementrian Kesehatan Republik Indonesia, Badan Pengembangan dan Pemberdayaan Sumber Daya Manusia Kesehatan, 2016.

[4] S. Aisara, S. Azmi, M. Yanni, "Gambaran Klinis Penderita Penyakit Ginjal Kronik yang Menjalani Hemodialisis di RSUP Dr. M. Djamil Padang”, Jurnal Kesehatan Andalas, vol. 7, no. 1, hlm. 42-50, 2018.

[5] A. Sutresno, F. Haryanto, S. Viridi, I. Arif, 'Investigation Monte
Carlo Simulation for 3 Compartment Model as Biology System in Urinary", American Scientific Publishers, vol. 7, no. 10, pp. 888-891, 2015.

[6] Yahya, "Perbedaan Tingkat Laju Osmosis Antara Umbi Solonum Tuberosum dan Doucus Carota", Jurnal Biology Education, vol. 4, no. 1, pp. 196-206, 2015.

[7] H.C. Berg, "Randoms Walks in Biology", New and Expanded Edition, Princenton University Press, 1992.

[8] J.P. Dilger, "Monte Carlo Simulation if Buffered Diffusion into and out of a Model Synapse", Biophysical Journal, vol. 98, pp. 959-967, 2010. 